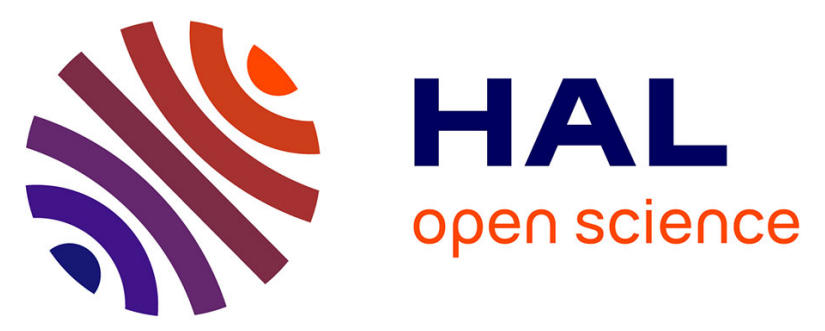

\title{
Impacts of Automakers Milk Run Collect System on Suppliers Planning and on Urban City Emissions
}

Claudia Meucci Andreatini, José Benedito Sacomano, Gilberto Gandelman

\section{To cite this version:}

Claudia Meucci Andreatini, José Benedito Sacomano, Gilberto Gandelman. Impacts of Automakers Milk Run Collect System on Suppliers Planning and on Urban City Emissions. IFIP International Conference on Advances in Production Management Systems (APMS), Sep 2014, Ajaccio, France. pp.122-129, 10.1007/978-3-662-44736-9_15 . hal-01387855

\section{HAL Id: hal-01387855 \\ https://inria.hal.science/hal-01387855}

Submitted on 26 Oct 2016

HAL is a multi-disciplinary open access archive for the deposit and dissemination of scientific research documents, whether they are published or not. The documents may come from teaching and research institutions in France or abroad, or from public or private research centers.
L'archive ouverte pluridisciplinaire HAL, est destinée au dépôt et à la diffusion de documents scientifiques de niveau recherche, publiés ou non, émanant des établissements d'enseignement et de recherche français ou étrangers, des laboratoires publics ou privés. 


\title{
Impacts of Automakers Milk Run Collect System on Suppliers Planning and on Urban City Emissions
}

\author{
Claudia Andreatini1, José Benedito Sacomano1, Gilberto Gandelman 2 \\ ${ }^{1}$ Paulista University-UNIP, Graduate Program in Production Engineering, Dr. Bacelar St. \\ 1212,São \\ Paulo,Brazil \\ ${ }^{2}$ Estrateggia - Management Consulting, Roberto Augusto Tavares St.107,São José dos \\ Campos, Brazil \\ \{Claudia Meucci Andreatini, andreatini@unip.com.br\}
}

\begin{abstract}
The milk run system is widely employed on the automotive of industry worldwide. Its usage is derived from an increasing demand of inventory reduction components and finished goods in the whole automotive supply chain. The aim of this paper is to evaluate the benefit perceived by both car manufacturers and suppliers and to analyze the implementation impacts. This evaluation will be based on field research in which the results are based. Another point with great importance nowadays is the energetic efficiency of the milk run in comparison to the conventional routes. As the milk run circuit is not optimized for minimum fuel consumption, we will present, in terms of quantitative calculations for representatives routes, what is the emission penalty of the milk run compared with conventional collect system.
\end{abstract}

Keywords. : Milk Run, $\mathrm{CO}_{2}$ emission, Load Factor, Supply Chain Integration,

\section{Introduction}

Optimizing Inventory level has been a challenge during the last 40 years. As long as the market became more competitive, launching new products with a higher mix and shorter lead times. The industries realized that with this more aggressive road map evolution, the uncertainty in sales forecast and the risk of material obsolescence became a real danger to the financial health of the companies.

A breakthrough in the production management system was done by Toyota [1]. It broke the paradigm in the production systems. The commercial demand "pulls" all the production instead of the previous model in which the production "pushes" the sales. The lean manufacturing concepts then were one of the key factors to achieve operational efficiency and to reduce components, "work-in-process" and finish goods inventories. In the automotive segment, the car manufacturers realized that the achievement of a "lean" concept would not be possible without the participation and implementation of this philosophy also by the suppliers. Some work has been done in simulating the supply chain material flow $[2,3,4]$.

The deliveries of the suppliers became than in lower volumes and higher frequency to minimize stocks at both automaker and supplier side. The milk run logistics [5] arises 
as a solution to consolidate a group of geographically nearby suppliers in only one vehicle (under responsibility of the car maker) that collect the parts in a predetermined route at a very precise time window.

The concept of milk run was created based on the diary industry delivery method a long time ago. The milk was delivered door to door on a daily base, as the milk could not endure more than one day at the consumer house, which means that the costumer could not store milk. The product was delivered in a pre determined route and time window. This concept applied to the automotive segment means that the car maker can collect from many suppliers at a high frequency rate and in a predefined route small quantities of parts to minimize their stocks.

Therefore the transport vehicle occupation is optimized by introducing more suppliers into the route. The milk run has been in operation in Brazil for a long time with a great acceptance by the automotive community. We will first evaluate and confirm this perception in chapter 2 and will analyze the fuel consumption and consequently the environmental impact of milk run in chapter 3.

\section{Impacts on automakers - suppliers relationship \& procedures}

The integrated supply chain between car manufacturers and tear 1 suppliers is well established in Brazil. The idea is that the logistics becomes more efficient all over the chain [6]. Many factors contributed to this integration: lean manufacturing concepts (just in time), IT technology with Material Resource Planning (MRP), Electronic Data Interchange (EDI) that enables on-line orders to suppliers. All these factors contributed to fine tune the orders / deliveries in such a way that the automaker places orders in small quantities to avoid stocks and the supplier has to accomplish that with lower production lots and consequently set the PCP and MRP accordingly.

The milk run then appeared as a good transportation solution to the mentioned context in such a way that small lots could be transported from the suppliers to the customers with a highest possible occupation of the transport vehicle.

As a natural evolution of car manufacturers and suppliers relationship, the milk run system demands an integrative (win-win) type of relationship with high degree of interaction between them $[7,8]$. In the past, the relationships were from a distributive type (zero-sum) focusing more on immediate results.

In order to evaluate the impact and the perception of the milk run at car makers and suppliers operations we made a field research and the results are shown on table 1. The survey was responded by 5 automakers and 8 suppliers.

It can be observed that the milk run is seen by both sides as a very good system for achieving operational efficiency. The profit improvement is sensed more by the automakers side $(100 \% \times 62 \%)$ as, normally, the smaller tear 1 suppliers cannot apply milk run to their own sub-suppliers. Therefore, although the finished goods stock level is limited, the components stock tends to be high at supplier side

From the overall stock level point of view, the suppliers sense a more positive impact $(75 \% \times 50 \%)$ as the stock of finished goods is reduced. On the other hand the automakers always applied a policy of receiving small lots from the local suppliers, 
independent on the milk run system. Therefore, the main advantage for the automakers is the transport cost optimization rather than components stock.

Table 1. Automakers / Suppliers in Brazil Survey

\begin{tabular}{|l|c|c|c|c|}
\hline & \multicolumn{2}{|c|}{ Automakers } & \multicolumn{2}{c|}{ Suppliers } \\
\hline & $\mathbf{Y}$ & $\mathbf{N}$ & $\mathbf{Y}$ & $\mathbf{N}$ \\
\hline Does your company apply the milk run with the suppliers? & $100 \%$ & $0 \%$ & $29 \%$ & $71 \%$ \\
\hline Has Milk run brought an inventory reduction? & $33 \%$ & $67 \%$ & $71 \%$ & $29 \%$ \\
\hline Was PCP affected by the introduction of milk run? & $33 \%$ & $67 \%$ & $100 \%$ & $0 \%$ \\
\hline $\begin{array}{l}\text { Has milk run brought any improvement in terms of } \\
\text { loading/unloading? }\end{array}$ & $100 \%$ & $0 \%$ & $71 \%$ & $29 \%$ \\
\hline Has milk run reduced freight costs? & $100 \%$ & $0 \%$ & $71 \%$ & $29 \%$ \\
\hline
\end{tabular}

\begin{tabular}{|l|l|c|c|c|c|c|c|}
\hline & \multicolumn{3}{|c|}{ Automakers } & \multicolumn{3}{|c|}{ Suppliers } \\
\hline \begin{tabular}{l}
\hline \\
\hline
\end{tabular} & & + & $=$ & - & + & $=$ & - \\
company milk run implementation affects the & $100 \%$ & $0 \%$ & $0 \%$ & $57 \%$ & $43 \%$ & $0 \%$ \\
\hline
\end{tabular}

\begin{tabular}{|l|c|c|c|c|c|c|c|c|}
\hline & \multicolumn{4}{|c|}{ Automakers } & \multicolumn{4}{c|}{ Suppliers } \\
\hline & $0-$ & $25-$ & $50-$ & + & $0-$ & $25-$ & $50-$ & + \\
$25 \%$ & $50 \%$ & $75 \%$ & $75 \%$ & $25 \%$ & $50 \%$ & $75 \%$ & 75 \\
$\%$
\end{tabular}

\section{Impact on emissions and load factor}

The movement of goods in urban areas is quite representative in terms of emissions. It represents from $20 \%$ to $30 \%$ of the overall kilometers traveled and from $16 \%$ to $50 \%$ of urban emission due to transportation [9]. As in Brazil the fleet age is higher in comparison to USA, Japan and Europe it is likely that the emission reaches closer to $50 \%$ rather than $16 \%$.

As emissions are a crucial issue, it is very important to analyze the impact of the milk run system on the fuel consumption and consequently on the emission of $\mathrm{CO}_{2}$.

\subsection{The "1D" path}

Arvidsson [10] analyzed the fuel consumption and the fuel emission of a milk run system for a distribution center case considering one distribution center and 4 delivery points. The main goal of the article was to show the called load factor paradox for milk run system. The load factor is the ratio between the actual and maximum load of a truck. While in general, higher load factors represent a better utilization of the commercial vehicle, it is shown that in a milk run circuit it occurs in an opposite way: 
The lower fuel consumption and $\mathrm{CO}_{2}$ emission occur for the path with the average lower load factor.

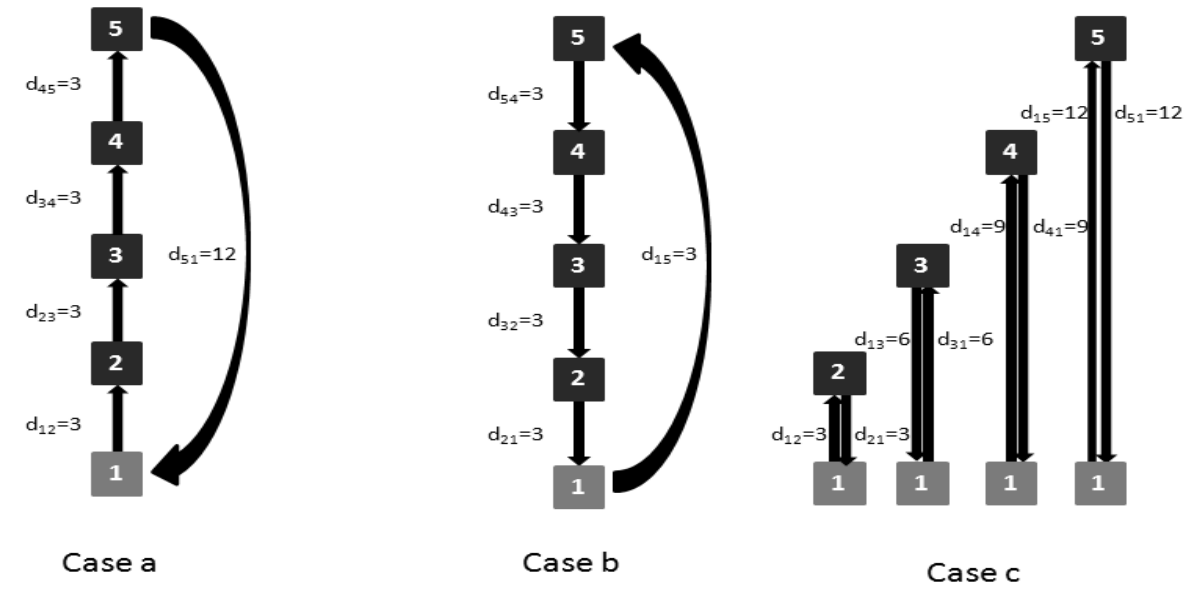

Fig. 1. Path configuration for the "1D" cases

In his example, it was considered an equally spaced delivery points separated by 1,25 kilometers. We will consider here the same geometry (fig. 1), but the analysis will be focused on the milk run collect points instead, where node 1 represents the automaker while nodes 2, 3, 4 and 5 represent the suppliers. The suppliers lie on a straight line starting from the automaker and we will call it a 1D trajectory. The truck starts from point 1 empty, collects the goods on the suppliers and return to the automaker where the parts will be assembled. The distance between the suppliers are 3 Kilometers to be more coherent with great São Paulo automotive industrial area, but the value itself is not important as we perform a comparative analysis. We will simulate 3 cases as follows:

a) Milk run clockwise, where the truck runs most of the path with a high load factor and collect $1 / 4$ of the load in each supplier.

b) Milk run counter - clockwise, where the truck runs most of the path with a low load factor and collect $1 / 4$ of the load in each supplier

c) Conventional pick up with 1 closed trip per supplier where the vehicle collect the maximum possible load. After the four trips the material collected is 4 times as compared with one single loop of cases a and b.

The fuel consumption depends on the traffic conditions, driver, vehicle type and load. We utilize here a distribution truck [10] with 8,5 tons maximum load and 5,5 kilometers unloaded weight. The urban fuel consumption used is given by the following formula $[10,11]$ where the result is in liters:

$$
\text { Urban Fuel Consumption }=\sum_{\mathrm{ii}} 0,057767 \times \operatorname{dij}(\mathrm{w}+\mathrm{Iij})^{0,6672}(1)
$$

Where dij is the distance in Kilometers between nodes $\mathrm{i}$ and $\mathrm{j}$, w is the vehicle weight and Iij is the load carried in each path segment $\mathrm{ij}$. 
Therefore the calculation of the fuel consumption in each path, reminding that for a and $b$ cases the vehicle must perform 4 complete cycles to transport the same amount of material as in case c.

Case a: Milk Run Clockwise

$=4 \times 0,057767 \times 3\left(5,5^{0,6672}+(5,5+2,13)^{0,6672}+(5,5+4,25) 0,6672+\right.$ $\left.(5,5+6,38)^{0,6672}\right)+4 \times 0,057767 \times 12(5,5+8,5)^{0,6672}=\mathbf{2 7 , 7 6}$ liters

Case b: Milk Run Counter clockwise

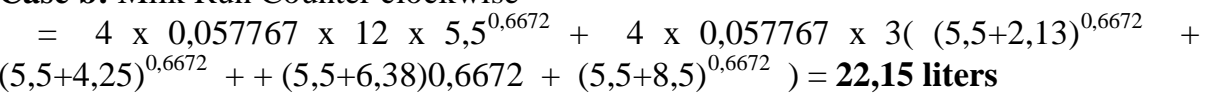

Case c: Conventional pick up in each supplier

$$
\begin{aligned}
& \quad=0,057767 \times 3\left(5,5^{0,6672}+(5,5+8,5)^{0,6672}\right)+0,057767 \times 6\left(5,5^{0,6672}+\right. \\
& \left.(5,5+8,5)^{0,6672}\right)+ \\
& \quad+0,057767 \times 9\left(5,5^{0,6672}+(5,5+8,5)^{0,6672}\right)+0,057767 \times 12\left(5,5^{0,6672}+\right. \\
& \left.(5,5+8,5)^{0,6672}\right)=\mathbf{1 6 , 1 3} \text { liters }
\end{aligned}
$$

The conventional pick up method by filling the vehicle with only one supplier part per circuit is the most efficient in terms of consumption and consequently $\mathrm{CO}_{2}$ emission. It should be reminded that in this specific case the inventory level for the automakers will be in average four times greater by compared with the milk run approaches. We summarized the results in table 2 where it is used a conversion rate of $2,66 \mathrm{~kg} \mathrm{CO}_{2} / 1$ for Diesel [11]. The average load factor (average load/ maximum load) is also calculated as well as the number of kilometers for each case. It can be seen that the best solution (low load factor) of milk run path has a 37,32\% more emission than the conventional pick up as long as the distance traveled is reduced.

Table 2. Results for the "1D" analysis

\begin{tabular}{|c|c|c|c|c|c|}
\hline Case & $\begin{array}{c}\text { Fuel } \\
\text { Consumption }\end{array}$ & $\begin{array}{c}\mathrm{CO}_{2} \\
\text { Emission }\end{array}$ & $\begin{array}{c}\text { MilkRun } \\
\text { Emission penalty }\end{array}$ & $\begin{array}{c}\text { Average } \\
\text { Load Factor }\end{array}$ & $\begin{array}{c}\text { Total Path } \\
\text { Lenght }\end{array}$ \\
\hline $\mathrm{a}$ & 27,76 lts & $73,84 \mathrm{~kg}$ & $73,11 \%$ & 0,69 & $96 \mathrm{~km}$ \\
\hline $\mathrm{b}$ & $22,15 \mathrm{lts}$ & $58,92 \mathrm{~kg}$ & $37,32 \%$ & 0,31 & $96 \mathrm{~km}$ \\
\hline $\mathrm{c}$ & $16,13 \mathrm{lts}$ & $42,90 \mathrm{~kg}$ & $0,00 \%$ & 0,50 & $60 \mathrm{~km}$ \\
\hline
\end{tabular}

\subsection{The "2D" path}

We performed so far all the analysis by choosing a somehow specific geometry where all the OEM - suppliers locations are aligned (1D). An important question which rises is if this alignment does not exist anymore, how the emission penalty for the milk run will vary. In order to model this more generic case, we utilize a path configuration utilizing 1 automaker (node 1) and 2 suppliers (nodes 2 and 3) as it can be seen in figure 2 . 


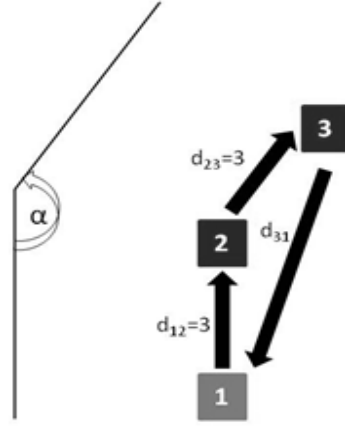

Case a

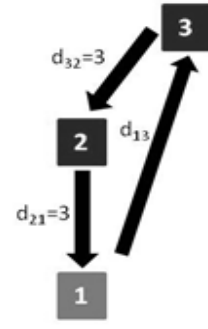

Case $b$

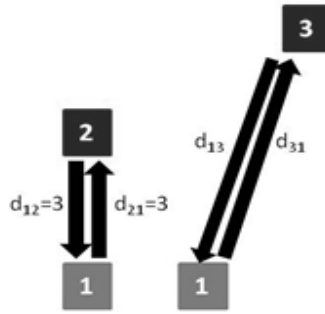

Case c

Fig. 2. Path configuration for the "2D" cases

In this case the distance from automaker to supplier $1\left(\mathrm{~d}_{12}\right)$ is $3 \mathrm{~km}$, the distance from supplier 1 to supplier $2\left(d_{23}\right)$ is $3 \mathrm{~km}$ and the distance from supplier 2 to OEM $\left(\mathrm{d}_{13}\right)$ is function of the path angle $\alpha$, where it can be expressed by using the simple trigonometric triangle relation:

$$
d_{13}=d_{31}=\left(3^{2}+3^{2}-2 \times 3 \times 3 \times \cos (\alpha)\right)^{0,5}=4,243(1-\cos \alpha)^{0,5}
$$

For the particular case where $\alpha=180^{\circ}$ we come back to the "1D" path and consequently $d_{13}=d_{31}=6 \mathrm{Km}$.

The calculation of the fuel consumption as a function of the angle $\alpha$ is then straightforward by combining equations (1) and (2). The following relations are then obtained for the fuel consumption, reminding that a complete cycle of case $\mathrm{c}$ corresponds to 2 cycles of the milk run cases $a$ and $b$.

Case a: Milk Run Clockwise

$$
\begin{aligned}
& =2 \times 0,057767 \times 3 \cdot\left(5,5^{0,6672}+(5,5+4,25)^{0,6672}\right)+ \\
& +2 \times 0,057767 \times 4,243 \cdot(1-\cos \alpha)^{0,5} \cdot(5,5+8,5)^{0,6672}
\end{aligned}
$$

Case b: Milk Run Counter Clockwise

$$
\begin{aligned}
& =2 \times 0,057767 \times 4,243(1-\cos \alpha)^{0,5} \cdot 5,5^{0,6672} \\
& +2 \times 0,057767 \times 3 .\left((5,5+4,25)^{0,6672}+(5,5+8,5)^{0,6672}\right)
\end{aligned}
$$

Case c: Conventional pick up in each supplier $=0,057767 \times 3 \cdot\left(5,5^{0,6672}+(5,5+8,5)^{0,6672}\right)+$

$$
\begin{aligned}
& =0,057767 \times 4,243 \cdot(1-\cos \alpha)^{0,5} \cdot\left(5,5^{0,6672}+(5,5+8,5)^{0,6672}\right)
\end{aligned}
$$

We can observe in figure 3, the $\mathrm{CO}_{2}$ emission for the three cases. The conventional delivery is always better than the 2 milk run cases. Besides, by comparing the milk run clockwise and counter clockwise it can be seen that for $\alpha<60^{\circ}$ the clock wise 
option is better as far as $d_{31}<d_{12}$ and this path represents the minimum average load factor. In this case the conventional delivery introduces a double inventory in comparison to the milk run.

The emission penalty of the milk run strategies (cases a and b) with respect to the conventional strategy among all possible angles $\left(0^{\circ}\right.$ to $\left.180^{\circ}\right)$ is shown in figure 4 .

\subsection{Correlation between the 1D and 2D approaches.}

As can be shown in the figures 3 and 4 we can realize that the $180^{\circ}$ condition (which is indeed the $1 \mathrm{D}$ case) is the most demanding in terms of fuel and consequently emissions which is quite intuitive as long as the $d_{13} \& d_{31}$ segments reach the maximum value of $6 \mathrm{~km}$. But the most important conclusion comes from figure 4 where for the $1 \mathrm{D}\left(180^{\circ}\right)$ condition, the milk run penalty with respect to the conventional system reaches the minimum value of $24,03 \%$. If we come back to the 1D table 1 we can see that for the case of 4 suppliers the emission penalty is $37,32 \%$. Therefore more suppliers in the path will lead to a higher emission penalty of the milk run. The penalty will increase as the angle becomes smaller then $180^{\circ}$ which represents a more realistic geometry.

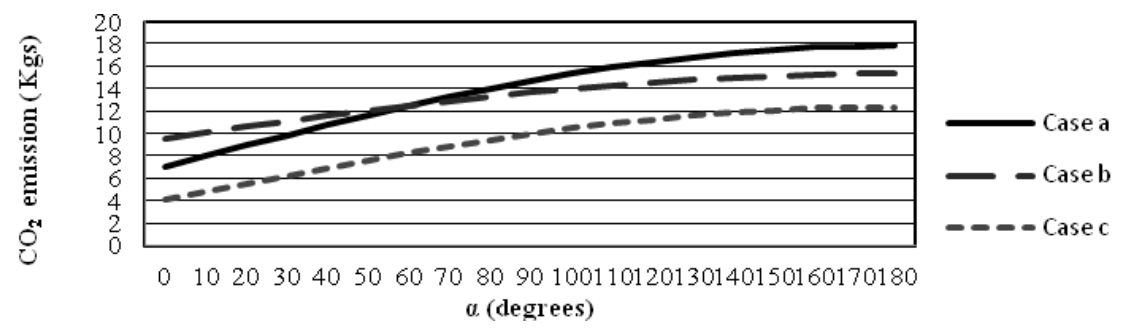

Fig. 3. $\mathrm{CO}_{2}$ emission as function of path angle

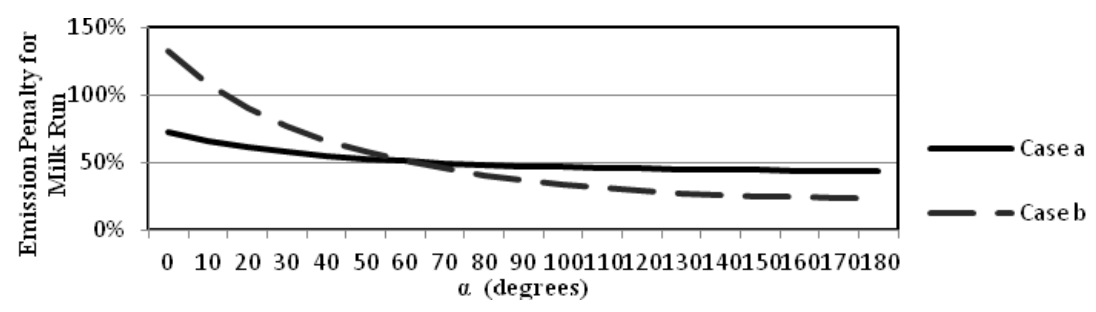

Fig. 4. . $\mathrm{CO}_{2}$ emission penalty for milk run collect system as function of path angle

It is important to mention that we did not consider in this study some factors which will tend to increase the penalty further. The first is that, as in the milk run due to more pickups at the suppliers, the maneuver of the vehicle represents an extra fuel burden, especially in the great São Paulo area where the maneuver conditions are very tight. Also, as the milk run collect window is narrower in comparison with the conventional window, there is less flexibility for a more efficient route planning to avoid traffic jams and detours due to restricted time zones. 


\section{Conclusions}

We have shown in this article some important points regarding the milk run collect system between the automakers and suppliers. It has been gradually adopted as an important tool for minimizing the inventory level for both automakers and tear1 suppliers. On the other hand, it generates an extra amount of fuel and consequently emission. Depending on the suppliers and automakers location geometry, the emission penalty for the milk run can reach $70 \%$ over of the conventional delivery for the case of 2 suppliers, while it can increase further as there are more suppliers. Consequently a detailed route planning accounting for fuel consumption must be performed to minimize the emission penalty.

\section{$5 \quad$ References}

1. Sugimori Y.;. Kusunoki K ;. Cho F, Uchikawa, S ,"Toyota Production System and Kanban System Materialization of Just-In-Time and Respect-for-Human System" International Journal of Production Research, pp. 553 - 564 (1977)

2. Kleijnen, P.C.-"Supply chain Simulation Tools and Techniques: a Survey". International Journal of Simulation \& Process Modeling,Volume 1, N..1/2 (2005)

3. Gandelman, G, Hemerly, E.M.: "HS3CM - A New Formulation for Supply Chain Modeling" ,SAE Technical Paper Series - 2011 -36-0068 E (2011)

4. Shi, W., Shang, J., Liu, Z., Zuo, X. : "Optimal Design of the Auto Parts Supply Chain for JIT Operations: Sequential Bifurcation Factor Screening and Multi-Response Surface Methodology, European Journal of Operational Research 236 664-676 (2014).

5. Moura, D.A. , Botter , R.C., "Caracterização do Sistema de Coleta Programada de Peças, Milk Run" RAE-eletrônica, Volume 1, Número 1, jan-jun (2002).

6. Guarnieri, P. Hatakeyama, K,:"Formalização da Logística de Suprimentos: Caso das Montadoras e Fornecedores da Indústria Automotiva Brasileira, Produção, v. 20, n. 2, abr./jun, p. 186-199, doi: 10.1590/S0103-65132010005000020, (2010).

7. Vanalle, R.M., Salles, J.A,A.,: " Relationship Between Assemblers and Suppliers: Theoretical Models and Case Studies in the Brazilian Auto Industry" , Gest. Prod., São Carlos, v. 18, n. 2, p. 237-250, (2011).

8. Carvalhal, E. , Neto, A.A, Andrade, G.M., Araújo, J.V,: "Negociação e Administração de Conflitos", 3rd Edition, FGV Management, Serie Gerenciamento de Projetos, ISBN 97885-225-0969-0, (2012).

9. Dablanc, L.,: " Goods Transport in Large European Cities: Difficult to Organize, Difficult to Modernize." Transportation Research Part A: Policy and Practice 41, 280-285 (2007).

10. Arvidsson, N., "The Milk RunR: A Load Factor Paradox with Economic and Environmental Implications for Urban Freight Transport", Transportation Research Part A 51) $56-62$ (2013)

11. Liimatainen, H., Pöllänen, M.: "Trends of Energy Efficiency in Finnish Road Freight Transport 1995-2009 and Forecast to 2016". Energy Policy 38, 7676-7686, (2010). 